\title{
PENINGKATAN HASIL BELAJAR MATEMATIKA MATERI BANGUN DATAR SEGIEMPAT MELALUI MODEL PEMBELAJARAN ELPSA DENGAN PERMAINAN KSD BAGI SISWA KELAS VII A SMPN 2 PATEAN KENDAL SEMESTER 2 TAHUN PELAJARAN 2015/2016
}

\author{
Mustakim \\ Guru Matematika SMPN 2 Patean Kendal \\ e-mail: mustakim200671@gmail.com
}

\begin{abstract}
The problems of classroom action research are for students of class VII A SMPN 2 Patean Kendal 2nd Semester Academic Year 2015/2016: (1) Is ELPSA learning with the game KSD can improve learning outcomes Mathematical quadrilateral material?, (2) What ELPSA learning with games KSD can increase the activity of learning mathematics quadrilateral material?, and (3) How to change the behavior of students of class VII A after following learning learning ELPSA with KSD game on material quadrilateral? The study was conducted in two cycles each consisting of planning, implementation, observation, and reflection. Data collected through observation activities, teacher journals, student questionnaire, and test. Subjects were increased activity and results study A class VII SMPN 2 Patean Kendal, amounting to 22 learners with a composition of 12 male students and 10 female student. The study was conducted in January to April 2016. The indicators in this study were (1) More than $75 \%$ of students are actively involved in the learning process; (2) The average grade formative test at least 75 to $75 \%$ of students reach the minimum KKM is 75 ; (3) At least $85 \%$ of students are well behaved during the learning process. The results showed that (1) increased student learning outcomes seen from the highest value, lowest value, average, and mastery learning. In the first cycle the highest grade 86 increased 14 points to 100 in the second cycle, the lowest value of 54 increased 4 points to 58 in the second cycle, the average value of 74 increased by 12 points to 86 , and the learning completeness $51 \%$ increase $35 \%$ to $86 \%$; (2) All aspects of the students in learning activities is experiencing an increase in both activity visual, oral, listening, writing, drawing, metrics, mentally, and emotionally. The conclusions of this Class Action Research is a learning game ELPSA with KSD on quadrilateral materials can improve learning outcomes and activities as well as change the behavior of students of class VII A SMPN 2 Patean Kendal 2nd Semester Academic Year 2015/2016.
\end{abstract}

Keywords: build a flat rectangle, ELPSA learning models and game KSD, learning outcomes.

\begin{abstract}
ABSTRAK
Rumusan masalah dalam Penelitian Tindakan Kelas di SMP2 kelas VII A tahunajaran 2015/2016 adalah (1) Apakah pembelajaran ELPSA dengan permainan KSD dapat meningkatkan hasil belajar Matematika materi segiempat Semester 2 Tahun Pelajaran?, (2) Apakah pembelajaran ELPSA dengan permainan KSD dapat meningkatkan aktivitas belajar Matematika materi segiempat?, dan (3) Bagaimana perubahan perilaku siswa Semester 2 setelah mengikuti pembelajaran pembelajaran ELPSA dengan permainan KSD pada materi
\end{abstract}


segiempat? Penelitian dilakukan dalam dua siklus yang terdiri dari perencanaan, pelaksanaan, pengamatan, dan refleksi. Pengumpulan data, melalui pengamatan, jurnal guru, angket siswa, dan tes. Subjek penelitian adalah peningkatan aktivitas dan hasil belajar siswa kelas VII A SMPN 2 Patean Kendal yang berjumlah 22 siswa dengan komposisi 12 siswa putra dan 10 siswa putri. Penelitian dilakukan pada bulan Januari sampai dengan April 2016. Indikator dalam penelitian ini adalah (1) Lebih dari 75\% siswa terlibat aktif dalam proses pembelajaran; (2) Rata-rata nilai tes formatif minimal 75 dengan $75 \%$ siswa mencapai batas minimal KKM yaitu 75; (3) Minimal $85 \%$ siswa berperilaku baik selama mengikuti proses pembelajaran. Hasil penelitian menunjukkan bahwa (1) hasil belajar siswa meningkat dilihat dari nilai tertinggi, nilai terendah, rata-rata, dan ketuntasan belajar. Pada Siklus I nilai tertinggi 86 meningkat 14 point menjadi 100 pada Siklus II, nilai terendah 54 meningkat 4 point menjadi 58 pada Siklus II, rata-rata nilai 74 meningkat 12 point menjadi 86 , dan ketuntasan belajar $51 \%$ meningkat 35\% menjadi $86 \%$.; (2) Semua aspek aktivitas siswa dalam belajar mengalami peningkatan baik aktivitas visual, oral, mendengarkan, menulis, mengambar, metrik, mental, maupun emosional. Simpulannya adalah pembelajaran ELPSA dengan permainan KSD pada materi segiempat dapat meningkatkan hasil belajar dan aktivitas serta mengubah perilaku siswa.

Kata kunci: bangun datar segi empat, hasil belajar, pembelajaran ELPSA, permainan KSD.

Materi segiempat merupakan materi esensial dalam mata pelajaran Matematika sehingga diujinasionalkan dengan dua indikator yaitu (1) menentukan luas gabungan bangun datar dan (2) menyelesaikan soal cerita yang berhubungan dengan keliling bangun datar. Untuk mampu menentukan luas gabungan bangun datar dan menyelesaikan soal cerita yang berhubungan dengan keliling bangun datar, siswa harus mempelajari sifat-sifat bangun datar, keliling dan luas bangun datar, serta pemecahan masalah menggunakan konsep keliling dan luas bangun datar. Materi segiempat (persegipanjang, persegi, jajargenjang, belahketupat, layang-layang, dan trapesium) sangat penting untuk dikuasai siswa kelas VII karena menjadi materi prasyarat saat siswa duduk di kelas VIII mempelajari bangun ruang sisi datar (balok, kubus, prisma, dan limas).

Persentase penguasaan materi soal-Matematika Ujian Nasional SMP/MTs Tahun Pelajaran 2014/2015 SMP Negeri 2 Patean Tahun 2015 untuk dua indikator secara nasional seperti pada Tabel 1.

Tabel 1: Persentase Penguasaan Materi Soal-Matematika Ujian Nasional SMP/MTs Tahun Pelajaran 2014/2015.

\begin{tabular}{|c|c|c|c|c|c|}
\hline $\begin{array}{l}\text { No. } \\
\text { Urut }\end{array}$ & Kemampuan yang Diuji & Sekolah & Kota/Kab & Prop. & Nas \\
\hline 15 & $\begin{array}{l}\text { Menyelesaikan masalah yang berkaitan dengan } \\
\text { luas bangun datar }\end{array}$ & 29,92 & 30,63 & 33,87 & 46,21 \\
\hline 16 & $\begin{array}{l}\text { Menyelesaikan masalah yang berkaitan dengan } \\
\text { keliling bangun datar }\end{array}$ & 42,62 & 43,19 & 51,20 & 59,98 \\
\hline
\end{tabular}

Sumber: http://118.98.234.50/hun/daya_serap.aspx

Dari Tabel 1 dapat disimpulkan bahwa hasil belajar siswa SMPN 2 Patean Kendal berkaitan dengan segiempat masih rendah dibandingkan hasil belajar siswa siswa se-Kabupaten Kendal 
maupun propinsi Jawa Tengah bahkan secara Nasional. Hasil pengamatan peneliti pada aktivitas belajar siswa di kelas VII A saat pembelajaran materi segitiga tanggal, aktivitas siswa dalam proses pembelajaran masih rendah. Aktivitas siswa dalam proses pembelajaran masih didominasi dengan aktivitas yang tidak mendukung untuk pembelajaran misalnya bergurau dengan teman, berbicara halhal yang tidak berkaitan dengan pelajaran. Akibatnya hasil belajar siswa juga belum memuaskan, dari 22 siswa yang tuntas hanya 9 siswa $(40,91 \%)$ dengan rata-rata nilai 65 , nilai tertinggi 86 , dan nilai terendah 40 .

Permasalahan di atas perlu diantisipasi dengan penerapan pembelajaran yang tepat sejak kelas VII karena materi segiempat dipelajari siswa kelas VII. Pembelajaran yang di terapkan adalah pembelajaran ELPSA (Experiencies $(\mathrm{E})=$ Pengalaman; Language $(\mathrm{L})=$ Bahasa $($ Pengembangan Bahasa); Pictures $(\mathrm{P})=$ Gambar (Representasi Gambar); Symbols $(\mathrm{S})=$ Simbol (Representasi Simbol); Application (A) = Aplikasi pengetahuan (Penerapan Pengetahuan). Model ELPSA dikembangkan berdasarkan pada teori-teori pembelajaran konstruktivisme dan sifatnya sosial. Model ini memandang bahwa pembelajaran sebagai suatu proses aktif dimana para siswa mengkonstruksi sendiri caranya dalam memahami sesuatu melalui proses pemikiran individu dan interaksi sosial dengan orang lain.

\section{Identifikasi Masalah}

Berdasarkan latar belakang, permasalahan yang muncul dalam pembelajaran Matematika di SMP Negeri 2 Patean Kendal:1) Daya serap UN untuk indikator yang berkaitan dengan segiempat rendah; 2) Aktivitas siswa dalam pembelajaran masih rendah; 3) Hasil belajar Matematika siswa masih rendah; 4) Guru belum menerapkan pembelajaran yang aktif, kreatif, dan menyenangkan;

\section{Pembatasan Masalah}

Penelitian ini dibatasi pada penerapan model pembelajaran ELPSA dengan permainan KSD pada mata pelajaran Matematika materi segiempat sebagai upaya untuk meningkatkan aktivitas dan hasil belajar Matematika siswa kelas VII A SMPN 2 Patean Kendal Semester 2 Tahun Pelajaran 2015/2916. Aktivitas belajar siswa dalam penelitian adalah skor aktivitas belajar siswa yang diamati peneliti dan kolaborator, selama mengikuti proses pembelajaran ELPSA dengan permainan KSD. Sedangkan hasil belajar siswa dari 1) nilai hasil permainan KSD individu, 2) permainan KSD kelompok, 3) tugas membuat gambar segiempat di tamanku, dan 4) ulangan tes tertulis aspek pengetahuan Matematika. Pelaksanaan tindakan ketika siswa mempelajari Kompetensi Dasar 6.2 Mengidentifikasi sifat-sifat persegi panjang, persegi, jajargenjang, belah ketupat, layang-layang, dan trapesium dan Kompetensi Dasar 6.3 Menghitung keliling dan luas bangun segitiga dan segi empat serta menggunakannya dalam pemecahan masalah.

\section{Rumusan Masalah}

Rumusan masalah dalam penelitian tindakan kelas ini adalah (1) apakah pembelajaran ELPSA dengan permainan KSD dapat meningkatkan hasil belajar Matematika materi segiempat bagi siswa kelas VII A SMPN 2 Patean Kendal Semester 2 Tahun Pelajaran 2015/2016?; (2) apakah pembelajaran ELPSA dengan permainan KSD dapat meningkatkan aktivitas belajar Matematika materi segiempat bagi siswa?; (3) bagaimana perubahan perilaku siswa setelah mengikuti pembelajaran ELPSA dengan permainan KSD pada materi segiempat? 


\section{KAJIAN PUSTAKA}

\section{Belajar dan Hasil Belajar Siswa}

Menurut Hamalik, (2011:28), belajar adalah suatu proses perubahan tingkah laku yang meliputi pengetahuan, pengertian, kebiasaan, keterampilan, apresiasi, emosional, hubungan sosial, jasmani, budi pekerti, sikap. Jika seseorang telah belajar akan terlihat perubahan pada salah satu atau beberapa aspek tingkah laku. Sedangkan menurut Fajar (2005:10), belajar adalah suatu proses perubahan dalam diri seseorang yang ditampakkan dalam bentuk peningkatan kualitas dan kuantitas tingkah laku seperti peningkatan pengetahuan, kecakapan, daya fikir, sikap, dan kebiasaan. Dari pendapat di atas dapat diambil kesimpulan belajar adalah kegiatan psiko-fisik-sosio sehingga terjadi proses perubahan dalam diri siswa yang ditampakkan dalam bentuk peningkatan kualitas dan kuantitas dalam budi pekerti, sikap, emosional, pengetahuan, pengertian, daya pikir, kebiasaan, keterampilan, apresiasi, hubungan sosial, dan jasmani menuju ke perkembangan pribadi seutuhnya.

Untuk mengetahui berhasil tidaknya seseorang dalam belajar maka perlu dilakukan suatu evaluasi yang bertujuan untuk mengetahui berhasil tidaknya siswa setelah mengikuti proses pembelajaran. Hasil evaluasi dapat memperlihatkan tinggi rendahnya keberhasilan belajar siswa. Menurut Gagne (dalam Suprijono, 2010:7) hasil belajar meliputi informasi verbal, keterampilan intelektual, strategi kognitif, keterampilan motorik, dan sikap. Sedangkan menurut Bloom (dalam Suprijono, 2010:7), hasil belajar mencakup kemampuan kognitif, afektif, dan psikomotorik. Domain kognitif adalah knowledge (pengetahuan), comprehension (pemahaman, menjelaskan, meringkas, contoh), application (menerapkan), analysis (menguraikan, menentukan hubungan), synthesis (mengorganisasikan, merencanakan, membentuk bangunan baru), dan evaluation (menilai). Domain efektif adalah receiving (sikap menerima), responding (memberikan respon), valuing (nilai), organization (organisasi), characterization (karakterisasi), rountinized (rutin). Domain psikomotor mencakup keterampilan produktif, teknik fisik, sosial, manajerial, dan intelektual. Jadi dapat disimpulkan bahwa hasil belajar adalah perubahan perilaku secara keseluruhan bukan hanya salah satu aspek potensi kemanusiaan saja. Artinya hasil belajar tidak dilihat secara fragmentasi atau terpisah, melainkan komprehensif.

\section{Aktivitas Belajar Siswa}

Aktivitas belajar siswa merupakan kegiatan atau perilaku yang terjadi selama proses belajar mengajar. Terdapat banyak faktor yang dapat mempengaruhi belajar siswa. Menurut Slameto (2010: 54), faktor yang mempengaruhi belajar digolongkan menjadi dua, yaitu faktor intern dan faktor ekstern. (1) faktor intern meliputi (a) Faktor Jasmani. Faktor Jasmani terdiri dari kesehatan dan cacat tubuh; (b) Faktor psikologis. Terdapat tujuh faktor yang tergolong faktor psikologi yang mempengaruhi belajar, yaitu: intelegensi, perhatian, minat, bakat, motif, kematangan, kesiapan; (c) kelelahan, dibedakan menjadi dua, yaitu kelelahan jasmani dan kelelahan rohani. (2) ekstern meliputi (a) keluarga. Siswa yang belajar akan menerima pengaruh dari keluarga berupa cara orang tua mendidik, relasi antara anggota keluarga, suasana rumah tangga, dan keadaan ekonomi keluarga; (b) sekolah, banyak faktor sekolah yang mempengaruhi belajar maupun pembelajaran; (c) masyarakat. merupakan faktor ekstern yang juga berpengaruh terhadap belajar siswa. Paul D. Dierich (dalam Hamalik, 2011:172), mengelompok aktivitas belajar ke dalam 8 (delapan) kelompok, yaitu (1) Aktivitas visual: melihat gambar, mengamati eksperimen, demonstrasi, pameran, dan mengamati orang lain bekerja atau bermain; (2) Aktivitas lisan (oral): mengemukakan fakta atau prinsip, menghubungkan suatu kejadian, mengajukan pertanyaan, memberi saran, mengemukakan pendapat, wawancara, diskusi dan interupsi; (3) Aktivitas mendengarkan : penyajian bahan, 
percakapan atau diskusi, suatu permainan, radio; (4) Aktivitas menulis antara lain menulis cerita, laporan, memeriksa karangan, bahan-bahan kopi, rangkuman, mengerjakan tes, dan mengisi angket; (5) Aktivitas menggambar : membuat grafik, chart, diagram peta, dan pola; (6) Aktivitas metrik antara lain melakukan percobaan, memilih alat-alat, melaksanakan pameran, membuat model, menyelenggarakan permainan, menari, dan berkebun; (7) Aktivitas mental: merenungkan, mengingat, memecahkan masalah, menganalisis, melihat hubungan dan membuat keputusan; (8) Aktivitas emosional: minat, membedakan, berani, tenang.

Aktivitas belajar siswa dalam penelitian ini adalah (1) Visual/melihat (membaca buku paket/modul atau bacaan lainnya yang relevan dengan materi segiempat); (2) Oral/Lisan (mengajukan pertanyaan, mengemukakan pendapat); (3) Mendengarkan (penyajian bahan, mendengarkan percakapan atau diskusi); (4) Menulis (rangkuman segiempat pada Lembar Kegiatan Siswa dan Materi (LKSRM), mengerjakan tes fomatif dan akhir siklus/mengisi angket); (5) Menggambar sketsa segiempat); (6) Metrik (terlibat aktif dalam diskusi kelompok, permaian KSD); (7) Mental (memecahkan masalah konsep segiempat); (8) Emosional (minat dalam diskusi atau permainan KSD, berani mengambil keputusan).

\section{Pembelajaran ELSPA}

ELPSA (Experiences, Language, Pictures, Symbols, Application) dikembangkan oleh tim RIPPLE (Research Institute for Professional Practice, Learning \& Education) diketuai oleh Tom Lowrie dari Charles Sturt University Australia. ELPSA merupakan sebuah kerangka desain pembelajaran yang dibuat untuk konteks Indonesia sebagai hasil dari analisis data video TIMSS. Kerangka pembelajaran model ELPSA digunakan dalam mendesain bahan belajar Geometri untuk guru Matematika SMP di forum MGMP. Konsep Geometri diujicobakan di 5 MGMP di 5 propinsi (DKI Jakarta, Jawa Barat, Jawa Tengah, Sumatera Barat, dan Sulawesi Selatan) pada tahun 2014. Model ELPSA dikembangkan berdasarkan teori pembelajaran konstruktivisme bersifat sosial. Kerangka pembelajaran ELPSA dapat digambarkan seperti pada Gambar 1.

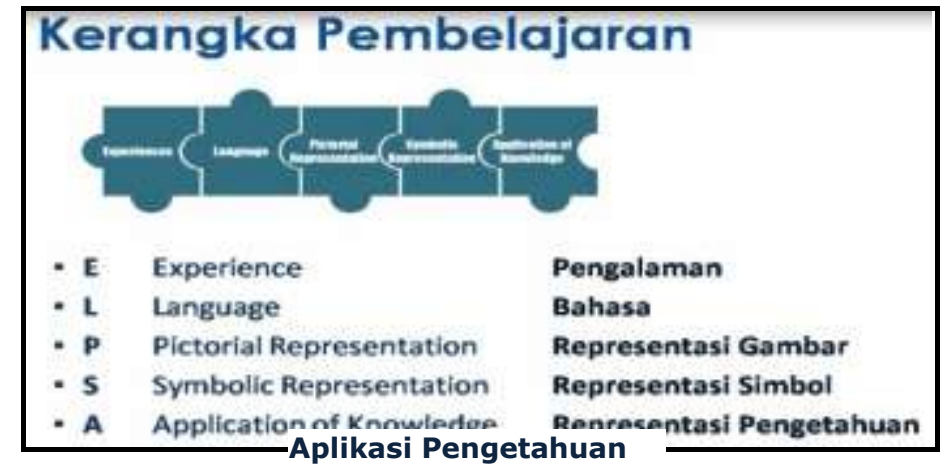

Gambar 1. Kerangka pembelajaran ELPSA

Model ini memandang bahwa pembelajaran sebagai suatu proses aktif dimana para siswa mengkonstruksi sendiri caranya dalam memahami sesuatu melalui proses pemikiran individu dan interaksi sosial dengan orang lain. Namun demikian ELPSA bukan suatu proses linear. Pembelajaran ELPSA dapat digambar seperti pada Gambar 2. 


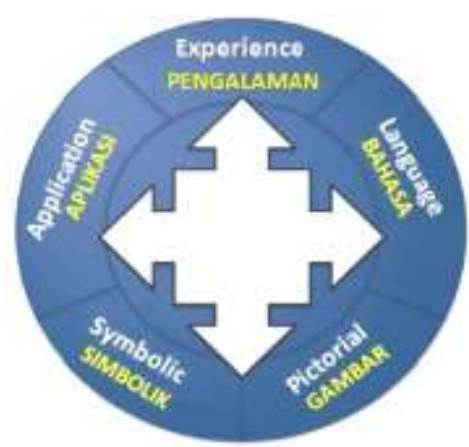

Gambar 2. Proses pembelajaran ELPSA tidak linier

Pembelajaran adalah proses kompleks yang tidak dapat diprediksi dan tidak terjadi dalam urutan linear, dengan demikian elemen dari model ELPSA dapat dilihat sebagai elemen yang saling berhubungan dan melengkapi. Model ELPSA tidak dibatasi untuk matematika saja. Komponen ELPSA dapat didiskusikan secara individu tetapi tidak dapat diterapkan secara terpisah, melainkan terkait satu sama lain dalam keseluruhan proses pembelajaran. Berikut ini diuraikan lebih detail tentang komponen ELPSA dalam pembelajaran.

1. Experiencies $(E)=$ Pengalaman, pembelajaran yang memunculkan pengalaman dimiliki siswa, menghubungkannya dengan pengetahuan dan pengalaman baru yang diperolehnya.

2. Language $(\mathrm{L})=$ Bahasa pembelajaran yang mengembangkan bahasa matematika tertentu agar dimaknai oleh siswa.

3. Pictures $(P)=$ Gambar pembelajaran yang memberikan pengalaman mengenal konsep matematika dalam bentuk gambar.

4. Symbols $(\mathrm{S})=$ Simbol (Representasi Simbol), pembelajaran yang dapat mengubah atau melakukan transisi dari representasi gambar ke representasi simbol.

5. Application $(A)=$ Aplikasi pengetahuan, pembelajaran yang berusaha memahami signifikansi proses belajar dengan dengan mengaplikasikan pengetahuan baru dalam memecahkan masalah dalam konteks yang bermakna.

Sintak Pembelajaran ELPSA dengan 5 langkah pokok (Experiencies, Language, Pictures, Symbols, dan Aplication) dapat disajikan pada Tabel 2.

Tabel 2: Sintaks Model Pembelajaran ELPSA.

\begin{tabular}{ll}
\hline \multicolumn{1}{c}{ Langkah } & \multicolumn{1}{c}{ Kegiatan Guru } \\
\hline Experiencies $(\mathrm{E})=$ & $\begin{array}{l}\text { Guru mengeksplisitkan atau memunculkan pengalaman terdahulu } \\
\text { yengalaman dimiliki siswa dan menghubungkannya dengan pengetahuan } \\
\text { dan pengalaman baru yang akan diperolehnya (dipelajari). }\end{array}$ \\
\hline Language $(\mathrm{L})=$ Bahasa & $\begin{array}{l}\text { Guru melakukan kegiatan pembelajaran yang secara aktif } \\
\text { mengembangkan bahasa matematika tertentu agar dimaknai oleh }\end{array}$ \\
& pembelajar. \\
\hline Pictures $(\mathrm{P})=$ Gambar & Guru melakukan kegiatan pembelajaran yang memberikan \\
(Representasi Gambar) & pengalaman mengenal konsep matematika dalam bentuk gambar. \\
\hline
\end{tabular}


Tabel 2: Lanjutan

\begin{tabular}{ll}
\hline \multicolumn{1}{c}{ Langkah } & \multicolumn{1}{c}{ Kegiatan Guru } \\
\hline $\begin{array}{l}\text { Symbols }(\mathrm{S})=\text { Simbol } \\
\text { (Representasi Simbol) }\end{array}$ & $\begin{array}{l}\text { Guru melakukan kegiatan pembelajaran yang dapat mengubah atau } \\
\text { melakukan transisi dari representasi gambar ke representasi simbol. }\end{array}$ \\
\hline $\begin{array}{l}\text { Application }(\mathrm{A})=\text { Aplikasi } \\
\text { pengetahuan }\end{array}$ & $\begin{array}{l}\text { Guru melakukan kegiatan pembelajaran yang berusaha memahami } \\
\text { signifikansi proses belajar dengan dengan mengaplikasikan } \\
\text { pengetahuan baru dalam memecahkan masalah dalam konteks } \\
\text { yang bermakna. }\end{array}$ \\
\hline
\end{tabular}

(Adaptasi dari Adi Wijaya, 2014).

\section{Permainan KSD}

Permainan KSD (Kuis Siapa Dia) pada PTK ini adalah permainan yang dibuat dari hasil modifikasi permainan Kuis Siapa Dia yang ditayangkan oleh stasiun TV Nasional dengan menebak bangun datar yang diletakkan dalam tempat khusus (dibuat dari kardus) dengan cara mengajukan pertanyaan kepada moderator (guru/peneliti). Jika tebakan benar mendapat skor 5 tebakan salah mendapat skor 1. Manfaat dari permainan KSD adalah mengeksplorasi kemamuan siswa tentang jenis segiempat dengan mengidentifikasi sifat-sifatnya. Permainan KSD dibagi dua yaitu permainan KSD kelompok dan permainan KSD individu. Langkah-langkah permainan KSD berkelompok adalah sebagai berikut. (1) Guru mengajukan pertanyaan pembuka misalnya "Siapa kalau sore hari nonton TV?"; "Siapa pang pernah nonton acara Kuis Siapa Dia?"; "Di stasiun TV mana kuis Siapa Dia Ditayangkan?"; (2) Guru menyampaikan pembelajaran dengan permainan KSD, yang ditebak bukan orang tapi bangun datar segiempat; (3) Guru menunjukkan segiempat dan mngajukan pertanyaan Siapa Dia? Untuk mengembangkan budaya sopan santun dan tertib siswa diminta menunjukkan jari sebelum menjawab; (4) Guru meminta siswa menyiapkan ringkasan materi segiempat yang sudah dibuat pada pertemuan sebelumnya; (5) Guru membagikan Kartu Pertanyaan Kelompok digunakan untuk menulis pertanyaan yang diajukan kepada moderator; (6) Guru memberikan kesempatan kepada masing-masing kelompok untuk mengajukan pertanyaan kepada moderator (secara bergiliran setiap anggota kelompok wajib mengajukan minimal satu pertanyaan). Apabila tidak mengajukan pertanyaan, maka kelompok tersebut mendapat nilai negatif 1 . Kegiatan ini untuk melatih siswa berani mengajukan pertanyaan; (7) Jika a semua anggota dalam kelompok sudah mengajukan pertanyaan, maka moderator mengunci permainan. Masing-masing kelompok diminta untuk berdiskusi menentukan Siapa Dia? dalam kotak. Jika jawaban benar mendapat skor 5, apabila jawaban salah mendapat skor 1. Guru mencatat perolehan skor pada lembar catatan perolehan skor; (8) Lembar Resume saling dipertukarkan, jawaban dikoreksi oleh kelompok lain. Perwakilan kelompok (digilir sehingga semua anggota dalam satu kelompok menyampaikan jawaban kelompok) untuk melatih siswa berani mengemukan pendapat.

Guru membagiakan Kartu Pertanyaan Individu; dan memberikan kesempatan kepada siswa untuk mengajukan satu pertanyaan kepada moderator. Apabila tidak mengajukan pertanyaan maka siswa tersebut mendapat nilai: Apabila siswa sudah mengajukan pertanyaan, maka moderator mengunci permainan. Siswa diminta untuk menentukan Siapa Dia dalam kotak dengan cara menuliskan jawabannya pada Kartu Pertanyaan. Jika jawaban benar mendapat skor 5, jika salah mendapat skor 1. Lembar Resume siswa saling dipertukarkan dengan teman satu meja, jawaban dikoreksi oleh siswa lain (Mustakim dan Solikhin, 2015). 


\section{Pembelajaran ELSPA dengan permainan KSD}

Pembelajaran ELPSA dengan permainan KSD, maka pembelajaran ELPSA dilakukan dengan langkah sebagai berikut (Mustakim, 2015). Kegiatan Pendahuluan, (1) Siswa dibimbing guru untuk menciptakan suasana pembelajaran pembelajaran yang religius, empati, peduli, dan disiplin dengan cara guru mengucapkan salam, meminta siswa duduk dengan tertib, mengecek kehadiran siswa terutama siswa yang tidak masuk dilanjutkan berdo'a untuk siswa yang sakit supaya segera sembuh. (2) Siswa diberi apersepsi dan motivasi untuk menumbuhkan keingintahuan siswa dan guru mengaitkan materi yang dipelajari dengan pengetahuan awal siswa melalui mengajukan pertanyaan berikut : Gambar apakah ini? (Guru menggambar segiempat di papan tulis), Benda-benda apakah di sekitarmu yang berbentuk segiempat? Motivasi: guru menyampaikan manfaat mempelajari dan menguasai materi segiempat (Experiencies); (3) Guru menyampaikan tujuan dan model pembelajaran yang akan diterapkan dan mengharapkan siswa selalu berpartisipasi aktif untuk melatih mandiri, percaya diri, bersikap demokratis dengan menghargai pendapat siswa lain.

Kegiatan inti, (1) Untuk menumbuhkan sikap demokratis siswa diminta duduk berkelompok sesuai dengan kelompok yang telah dibentuk oleh guru (tiap kelompok terdiri dari 5 siswa). Guru mengeksplisitkan atau memunculkan pengalaman terdahulu yang dimiliki siswa dan menghubungkannya dengan pengetahuan dan pengalaman baru yang akan diperolehnya (dipelajari) dengan cara mengajukan pertanyaan yang terkait dengan segiempat. Misalnya "Buku yang saya pegang ini berbentuk apa? Benda yang saya pegang (guru memegang kertas berukuran $20 \mathrm{~cm} \times 20$ $\mathrm{cm}$ ) berbentuk apa? Sebutkan benda-benda di sekitar kalian berbentuk segiempat? (Experiencies, Application) (Eksplorasi); (2) Guru melakukan pembelajaran secara aktif mengembangkan bahasa matematika tertentu agar dimaknai oleh siswa dengan cara guru menggunakan model segiempat dari kertas, selanjutnya guru mengajukan pertanyaan berkaitan dengan unsur segiempat (Language, Pictures) (Eksplorasi); (3) Guru melakukan pembelajaran untuk memberikan pengalaman mengenal konsep matematika dalam bentuk gambar dan mengajukan pertanyaan kepada siswa gambar apa bangun apa? (Pictures, Symbols); (4) Guru melakukan pembelajaran yang dapat mengubah atau melakukan transisi dari representasi gambar ke representasi simbol. Guru menggambar segiempat. Siswa dilatih untuk berpikir logis, cerdas, tangguh, kerja keras, dan kritis dengan cara guru mengajukan pertanyaan misalnya panjang persegi panjang disimbolkan $p$, lebar disimbolkan $I$, panjang sisi persegi disimbolkan s (Pictures, Symbols) (Elaborasi); (5) Guru melakukan pembelajaran yang berusaha memahami signifikansi proses belajar dengan dengan mengaplikasikan pengetahuan baru dalam memecahkan masalah dalam konteks yang bermakna dengan cara guru membagikan kegiatan Laboratorium Mini Matematika (Application) (Elaborasi); (6) Guru memfasilitasi kelompok yang mengalami kesulitan dalam menyelesaikan kegiatan Laboratorium Mini Matematika; (7) Guru memberikan kuis yang harus dijawab mandiri, anggota kelompok tidak boleh saling membantu; (7) Dengan bimbingan guru siswa membuat kesimpulan tentang persegi panjang dan persegi (Konfirmasi). Kegiatan Penutup, (1) Guru melakukan permainan KSD kelompok atau individu; (2) Dengan tanya jawab, siswa dibimbing untuk membuat rangkuman; (3) Refleksi proses pembelajaran; (4) Guru memberikan pekerjaan rumah/tugas mandiri.

\section{Materi Segiempat}

Standar Kompetensi, 6. Memahami konsep segi empat dan segitiga serta menentukan ukurannya. Kompetensi Dasar, 6.2 Mengidentifikasi sifat persegi panjang, persegi, jajargenjang, belah ketupat, layang-layang, dan trapezium. Sifat-sifat persegi panjang, (a) Panjang sisi-sisi yang berhadapan sama dan sejajar; (b) Keempat sudutnya siku-siku; (c) Panjang diagonal-diagonalnya 
sama dan saling membagi dua sama panjang; (d) Dapat menempati bingkainya kembali dengan empat cara. Persegi panjang adalah bangun datar segiempat yang memiliki dua pasang sisi sejajar dan memiliki empat sudut siku-siku. Sifat-sifat persegi, (a) Sisi-sisi berhadapan sejajar; (b) Keempat sudutnya siku-siku; (c) Panjang diagonalnya sama dan saling membagi dua sama panjang; (d) Panjang keempat sisinya sama; (e) Setiap sudutnya dibagi dua sama ukuran oleh diagonalnya; (f) Diagonalnya berpotongan saling tegak lurus. Persegi adalah persegi panjang yang keempat sisinya sama panjang. Sifat-sifat jajargenjang, (a) Sisi-sisi yang berhadapan sejajar dan sama panjang; (b) Sudut-sudut yang berhadapan sama ukuran; (c) Dua sudut yang berdekatan saling berpelurus; (d) Diagonal jajargenjang membagi daerah menjadi dua bagian sama besar; (e) Diagonalnya saling membagi dua sama panjang. Jajargenjang adalah segiempat yang setiap pasang sisinya yang berhadapan sejajar. Sifat-sifat belahketupat, (a) Semua sisinya sama panjang; (b) Sisi-sisi berhadapan sejajar; (c) Sudut-sudut berhadapan sama ukurannya; (d) Diagonalnya membagi sudut menjadi dua ukuran yang sama ukuran; (e) Kedua diagonalnya saling tegak lurus dan saling membagi dua sama panjang; (f) Diagonal membagi belahketupat menjadi dua bagian sama besar atau diagonalnya merupakan sumbu simetri; (g) Jumlah ukuran dua sudut berdekatan $180^{\circ}$. Belahketupat adalah segiempat semua sisinya sama panjang.

Sifat-sifat layang-layang, (a) Panjang dua sisi berdekatan sama; (b) Sepasang sudut berhadapan ukuran; (c) Salah satu diagonalnya membagi layang-layang menjadi dua ukuran yang sama; (d) Diagonal-diagonalnya saling tegak lurus dan salah satu diagonalnya membagi diagonal yang lain menjadi dua sama panjang. Layang-layang adalah segiempat yang dibentuk dari gabungan dua buah segitiga sama kaki yang alasnya sama panjang dan berimpit (Dewi Nuharini dan Tri Wahyuni, 2008).

Sifat-sifat trapesium, (a) Sepasang sisi yang berhadapan sejajar; (b) Jumlah ukuran dua sudut yang berdekatan antara dua sisi sejajar adalah 180\%; (c) Pada trapesium sama kaki ukuranukuran sudut alasnya sama, panjang diagonal-diagonalnya sama, dan menempati bingkainya dengan dua cara); (d) Pada trapesium siku-siku mempunyai tepat dua sudut siku-siku). Trapesium adalah segiempat yang mempunyai tepat sepasang sisi yang berhadapan sejajar. Kompetensi Dasar 6.3 Menghitung keliling dan luas bangun segitiga dan segi empat serta menggunakannya dalam pemecahan masalah. (a) Keliling persegi panjang $=2(p+I)$, dengan $p=$ panjang dan I = lebar; (b) Luas persegi panjang $=p \times I$. Keliling dan luas persegi, (a) Keliling persegi $=4 s$, dengan $s=$ panjang sisi persegi; (b) Luas persegi $=s \times s=s^{2}$. Keliling dan luas jajargenjang, (a) Keliling jajargenjang $=$ $2(p+I)$ dengan $p=$ panjang dan $I=$ lebar; (b) Luas jajargenjang $=a \times t$ dengan $a=$ alas jajargenjang $t$ $=$ tinggi jajargenjang. Keliling dan luas belahketupat, (a) Keliling belahketupat $=4 s$, dengan $s=$ panjang sisi belahketupat; (b) Luas belahketupat $=\frac{d_{1} \times d_{2}}{2}$ dengan $d_{1}=$ diagonal ke-1 dan $d_{2}=$ diagonal ke-2. Keliling dan luas layang-layang, (a) Keliling belahketupat $=2\left(s_{1}+s_{2}\right)$, dengan $s_{1}=$ panjang sisi ke-1 dan $s_{2}=$ panjang sisi ke-2; (b) Luas layang-layang $=\frac{d_{1} \times d_{2}}{2}$ dengan $\mathrm{d}_{1}=$ diagonal ke-1 dan $d_{2}=$ diagonal ke-2. Keliling dan luas trapesium, (a) Keliling trapesium $=a+b+c+$ $d$, dengan $a, b, c, d=$ panjang sisi-sisi trapesium; (b) Luas layang-layang $=\frac{(a+b) \times t}{2}$ dengan $a, b$ = panjang sisi-sisi sejajar trapesium, $\mathrm{t}=$ tinggi trapesium. (M.S. Wahyudi, Dyah Rini P, Mustakim, dan Muh. Arief K. 2014). 


\section{Penelitian yang Relevan}

Kerangka pembelajaran model ELPSA sudah diujicobakan pertama kali digunakan dalam mendesain bahan belajar Geometri untuk guru Matematika SMP yang digunakan di forum MGMP. Bahan belajar Geometri ini telah diujicobakan pada 5 MGMP di 5 propinsi (DKI Jakarta, Jawa Barat, Jawa Tengah, Sumatera Barat, dan Sulawesi Selatan) pada bulan Januari sampai dengan April 2014 (Adi Wijaya dkk., 2014).

Penelitian tentang penggunaan permainan KSD dalam pembelajaran sudah dilakukan oleh Mustakim dan Solikhin dengan penelitian berjudul "Peningkatan keberanian bertanya dan prestasi belajar dengan pembelajaran Think Pair Share (TPS) dengan Media Permainan KSD pada Materi Segitiga dan Segiempat Bagi Peserta Didik Kelas VII A SMP Negeri 2 Patean Semester 2 Tahun Pelajaran 2014/2015" menunjukkan bahwa keberanian peserta didik bertanya dengan kategori minimal berani mengalami peningkatan sebesar 34\% (dari kondisi awal sebanyak 44\% meningkat menjadi $78 \%$ pada Siklus II). Ketuntasan belajar mengalami peningkatan $41 \%$ (dari kondisi awal 37\% meningkat menjadi 78\% pada Siklus II) (Mustakim dan Solikhin, 2015). Dari hasil penelitian terdahulu, maka dapat diketahui penelitian tindakan kelas menerapkan model pembelajaran ELPSA dan permainan KSD telah dilakukan peneliti sebelumnya. Semakin memperkuat penerapan model pembelajaran ELPSA dan permainan KSD yang ditujukan dalam rangka meningkatkan kualitas pembelajaran.

\section{Kerangka Berpikir}

Model pembelajaran ELPSA yang terdiri dari 5 (lima) komponen yaitu Experiencies $(\mathrm{E})=$ Pengalaman, merupakan kegiatan pembelajaran yang mengeksplisitkan atau memunculkan pengalaman terdahulu yang dimiliki siswa dan menghubungkannya dengan pengetahuan dan pengalaman baru yang akan diperolehnya (dipelajari). Language $(\mathrm{L})=$ Bahasa (Pengembangan Bahasa) pembelajaran yang secara aktif mengembangkan bahasa matematika tertentu agar dimaknai oleh pembelajar. Pictures $(P)=$ Gambar (Representasi Gambar) pembelajaran yang memberikan pengalaman mengenal konsep matematika dalam bentuk gambar. Symbols $(\mathrm{S})=$ Simbol (Representasi Simbol) pembelajaran yang dapat mengubah atau melakukan transisi dari representasi gambar ke representasi simbol. Application (A) = Aplikasi pengetahuan, pembelajaran yang berusaha memahami signifikansi proses belajar dengan dengan mengaplikasikan pengetahuan baru dalam memecahkan masalah dalam konteks yang bermakna. Kelima komponen pembelajaran ELPSA dalam pelaksanaan pembelajaran tidak linier, elemen dari model ELPSA dapat dilihat sebagai elemen saling berhubungan dan melengkapi. Komponen ELPSA didiskusikan secara individu tetapi tidak dapat diterapkan secara terpisah, melainkan terkait satu sama lain dalam keseluruhan pembelajaran. Permainan KSD diyakini peneliti dapat mengeksplorasi pemahaman konsep siswa tentang segiempat (keliling dan luas segiempat, dan pemecahan masalah konsep segiempat) dengan tanya jawab dalam permainan setelah siswa mengalami pembelajaran ELPSA sehingga hasil belajar siswa dapat meningkat. Siklus I adalah penerapan model pembelajaran ELPSA dengan permainan KSD untuk submateri sifat-sifat segiempat, dilanjutkan dengan Siklus II menerapkan model pembelajaran ELPSA dengan permainan KSD untuk submateri keliling dan luas segiempat. Dari siklus I dan siklus II diharapkan aktivitas dan hasil belajar siswa meningkat. Pada kondisi akhir, melalui penerapan pembelajaran ELPSA dengan permainan KSD, aktivitas dan hasil belajar matematika materi segiempat bagi siswa kelas VII A meningkat. 


\section{Hipotesis Tindakan}

Penelitian tindakan kelas ini adalah (1) Proses pembelajaran ELPSA dengan permainan KSD untuk meningkatkan hasil belajar Matematika materi segiempat siswa kelas VII-A SMPN 2 Patean Kendal Semester 2 Tahun Pelajaran 2015/2016 terlaksana dengan efektif; (2) Melalui pembelajaran ELPSA dengan permainan KSD dapat meningkatkan hasil belajar dan (3) Melalui pembelajaran ELPSA dengan permainan KSD dapat mengubah perilaku siswa kelas.

\section{METODE PENELITIAN}

Kegiatan penelitian diawali dengan penyusunan proposal, penyusunan instrumen penelitian. Minggu ketiga dan keempat Februari 2016 dilakukan penelitian tahap awal (kondisi awal/pra siklus) sekaligus pengumpulan data dokumentasi. Tindakan penelitian baik Siklus I maupun Siklus II dilakukan pada bulan Maret 2016, selama tindakan penelitian dilakukan pengumpulan dan analisis data. Untuk kelas VII SMP Negeri 2 Patean Kendal memiliki empat rombongan belajar yakni VII A, VII B, VII C, dan VII D. Pelaksanaan penelitian tindakan kelas ini berlangsung di kelas VII A SMP Negeri 2 Patean Kendal disebabkan karena beberapa alasan, yaitu: pertama, siswa di kelas tersebut cukup heterogen dalam kemampuan, ekonomi, dan kepribadian; kedua, sifat pasif dan pendiam dari mayoritas siswa dalam kegiatan pembelajaran; dan ketiga, adanya rentang perbedaan hasil belajar yang jauh dari para siswa. Sumber data dalam PTK ini adalah aktivitas belajar, hasil belajar, dan perilaku siswa, dianalisis dan sebagai bahan diskusi dipaparkan pada Tabel 4.

Tabel 3: Sumber Data Penelitian.

\begin{tabular}{lccc}
\hline \multicolumn{1}{c}{ Data } & Kondisi Awal & Siklus I & \multicolumn{2}{c}{ Siklus II } \\
\hline Aktivitas belajar siswa & $\sqrt{ }$ & $\sqrt{ }$ & $\sqrt{ }$ \\
\hline Hasil belajar Siswa & $\sqrt{ }$ & $\sqrt{ }$ & $\sqrt{ }$ \\
\hline Perilaku siswa & $\sqrt{ }$ & $\sqrt{ }$ & $\sqrt{ }$ \\
\hline
\end{tabular}

\section{Teknik dan Alat Pengumpulan Data}

Dalam PTK dibutuhkan data yang dianalisis dan direfleksikan sehingga terbentuk sebuah perencanaan tindakan untuk perbaikan kondisi sebelumnya. Teknik pengumpulan data terdiri dari teknik tes dan teknik non tes. Teknik tes untuk data hasil belajar siswa, dan teknik non tes untuk data kualtitatif aktivitas belajar siswa dan perilaku siswa. Data hasil belajar digunakan lembar soal tes tertulis dan rubrik unjuk kerja. Data kualitatif digunakan data berupa lembar observasi, lembar angket, dan pedoman wawancara. Tahapan PTK disusun dalam siklus dengan 4 tahapan, yaitu (1) perencanaan, (2) tindakan, (3) pengamatan, dan (4) refleksi. Tahapan penelitian dilakukan dalam 2 (dua) siklus.

\section{Siklus 1}

Perencanaan, 1) Berdasarkan rumusan masalah yang diterapkan pembelajaran ELPSA dengan permainan KSD; 2) Dipilih materi yang sesuai dengan waktu yang tersedia (yakni 9 kali pertemuan terdiri dari 3 pertemuan setiap siklus, dan dilakukan dalam 3 siklus). Dipilih materi dan sifat-sifat segiempat, keliling dan luas segiempat, pemecahan masalah menggunakan konsep segiempat); (3) RPP untuk materi segiempat secara rinci untuk setiap pertemuan; (4) bahan dan dokumen yang diperlukan seperti daftar hadir, lembar kerja siswa berupa Laboratorium Mini Matematika I; (5) intrumen untuk mengamati proses dan hasil belajar dalam 3 pertemuan, termasuk 
merancang bagaimana menganalisisnya; (6) teman sejawat guru sebagai observer, dan membantu mendokumentasikan kegiatan PTK.

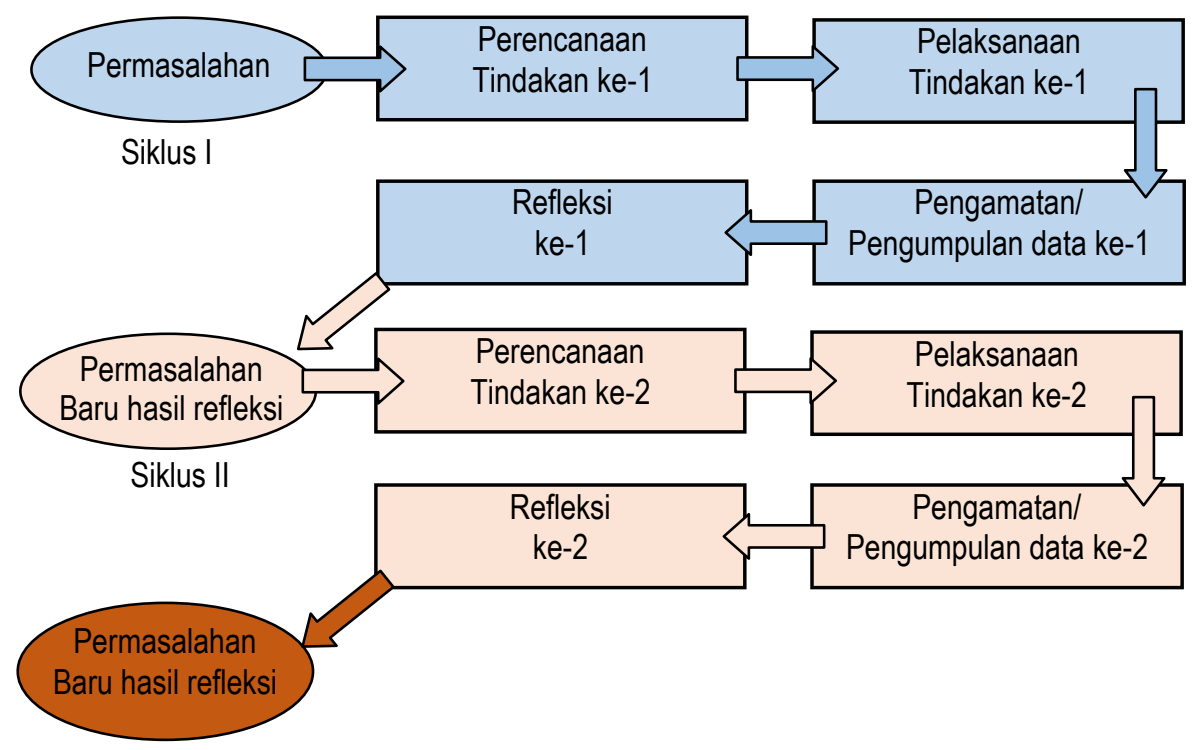

Gambar 3. Deskripsi pelaksanaan siklus

Pelaksanaan, kegiatan meliputi (1) Mengajar selama 3 kali pertemuan untuk submateri sifatsifat segiempat; yang sesuai dengan skenario pembelajaran yang telah disusun di RPP; (3) Mendokumentasikan kegiatan yang dilakukan dalam catatan pelaksanaan pembelajaran (Jurnal Guru). Pengamatan meliputi: (1) proses pembelajaran dan respon kelas serta siswa dengan memakai instrumen yang telah disiapkan; (2) mengamati proses pembelajaran yang dilakukan guru dengan memakai lembar observasi yang telah dirancang; (3) pengamatan hasil belajar dengan menggunakan tes, kuis permainan KSD, wawancara, atau instumen lainnya yang telah disiapkan; (4) semua hasil pengamatan dan menganalisisnya. Refleksi, meliputi : (1) hasil analisis pengamatan (baik proses maupun hasil pembelajaran) melakukan evaluasi untuk memperbaiki pembelajaran pada Siklus II; (2) Hasil refleksi dihimpun dalam satu catatan yang dipakai sebagai masukan dalam perancangan Siklus II.

Siklus II

Perencanaan, meliputi (1) merancang RPP untuk Siklus II dengan submateri keliling dan luas segiempat secara rinci untuk setiap pertemuan; (2) merancang skenario pelaksanaan pembelajaran model ELPSA dengan permainan KSD dalam Siklus II untuk 3 pertemuan dengan perbaikan dan penyempurnaan tindakan pembelajaran sesuai dengan masukan hasil refleksi Siklus I; menyiapkan media untuk submateri keliling dan luas segiempat serta dokumen daftar hadir, dan lembar kerja siswa Laboratorium Mini Matematika II; (3) Kembali merancang instrumen (sesuai dengan masukan refleksi) untuk mengamati proses pembelajaran dan hasil belajar dalam 3 kali pertemuan; (4) mendiskusikan dengan sejawat guru tentang hal-hal yang diperbaiki pada pembelajaran di Siklus II.

Pelaksanaan, meliputi (1) Melaksanakan pembelajaran di Siklus II dengan submateri melanjutkan dari Siklus I yaitu keliling dan luas segiempat; (2) menerapkan pembelajaran sesuai dengan skenario pembelajaraan ELPSA dengan permainan KSD. Perbedaan dengan tindakan pada 
Siklus I, pada Siklus II ada perbaikan atau penyempurnaan dari tindakan yang telah dilakukan pada Siklus I.

Tahap Pengamatan, kegiatannya antara lain (1) pengumpulan data baik proses maupun hasil pembelajaran dengan model pembelajaran ELPSA dengan permainan KSD; (2) menghimpun hasil pengamatan dan menganalisis hasilnya. Tahap refleksi pada Siklus II antara lain (1) Peneliti bersama guru mitra menganalisis hasil pengamatan (aktivitas dan perilaku siswa), dan tes hasil belajar Siklus II, dan membuat simpulan terhadap pencapaian indikator. Pada Siklus II indikator pencapaian dapat dipenuhi; (2) Mendiskusikan hasil analisis berdasarkan indikator pada lembar pengamatan dan tes hasil belajar Siklus II. Mengevaluasi bagian yang telah berhasil dicapai, dan layak ditindaklanjuti untuk kegiatan pembelajaran ELPSA dengan permainan KSD.

\section{HASIL PENELITIAN DAN PEMBAHASAN Deskripsi Kondisi Awal}

Sebelum penerapan model pembelajaran ELPSA dengan permainan KSD di kelas VII A dilaksanakan pembelajaran dengan model STAD bertukar pasangan dengan langkah-langkah (1) Siswa diminta untuk duduk berkelompok sesuai permintaan guru; (2) Siswa diminta membaca dan mempelajari Modul Pembelajaran Matematika untuk SMP/MTs Kelas VII; (3) Setiap anggota kelompok berdiskusi untuk menyelesaikan soal yang ada di Ayo Diskusi dan Latihan sehingga diperoleh jawaban yang benar dan memastikan tiap anggota kelompok dapat mengetahui jawabannya; (4) Siswa diminta guru untuk bertukar kelompok diskusi, agar menyelesaikan soal yang ada di Ayo Diskusi dan Latihan sehingga diperoleh jawaban yang benar; (5) Guru berkeliling kelas dan membimbing siswa menyelesaikan masalah terutama bagi yang kesulitan; (6) Dengan tayangan LCD, guru memberikan konfirmasi; (7) Guru memberikan pertanyaan kepada dan dijawab siswa saat menjawab kuis, anggota dalam satu kelompok tidak boleh membantu; (8) Dengan tayangan LCD, guru memberikan penjelasan dan membetulkan jika terjadi kesalahan; (9) Dengan bimbingan guru, siswa dapat membuat kesimpulan. Proses pembelajaran berlangsung dengan tenang. Namun ketenangan bukan berarti semua siswa melaksanakan aktivitas pembelajaran sesuai dengan harapan guru. Ketika guru melakukan penjelasan materi pelajaran ada yang melamun. Ketika diadakan Tanya jawab hanya anak tertentu yang aktif menjawab atau bertanya. Ketika kegiatan berdiskusi menyelesaikan soal Ayo Diskusi atau latihan banyak siswa yang melakukan aktivitas di luar skenario pembelajaran. Setelah waktu belajar Matematika hampir selesai, mereka hanya mencontek pekerjaan temannya yang sudah selesai tanpa mau bertanya (tidak bertanggung jawab). Setelah proses pembelajaran selesai diadakan tes formatif, mengukur keberhasilan proses pembelajaran. Nilai tertinggi yang dicapai siswa hanya 85 , dengan nilai terendah 40 , dan rata-rata nilai 65 . Sedangkan jumlah siswa yang tuntas belajar hanya 8 siswa atau $36 \%$ sehingga yang belum tuntas mencapai 14 siswa atau 64\%. Aktivitas belajar siswa pada proses pembelajaran dalam kategori kurang baik dengan rata-rata 42\%. Aktivitas siswa dalam kategori kurang baik antara lain (1) aktivitas oral//isan (mengajukan pertanyaan pada pembelajaran, mengemukakan pendapat/berdiskusi dengan teman satu kelompok); dan (2) aktivitas mental (memecahkan masalah yang berkaitan dengan konsep segitiga). Namun begitu sudah muncul aktivitas belajar siswa dalam kategori cukup baik antara lain (1) aktivitas visual/melihat (membaca buku paket atau modul atau bacaan lainnya yang relevan dengan materi segitiga); (2) Mendengarkan (penyajian bahan; percakapan atau diskusi); (3) Menulis (rangkuman tentang segitiga pada Lembar Kegiatan Siswa Rangkuman Materi (LKSRM); (4) Menggambar sketsa dari segitiga); (5) Metrik (terlibat aktif dalam diskusi kelompok); dan (6) Emosional (minat dalam diskusi). Secara keseluruhan aktivitas siswa 
dalam proses pembelajaran pada kategori kurang baik, untuk mencapai hasil belajar yang maksimal aktivitas belajar siswa perlu ditingkatkan minimal pada kategori baik.

Dampak dari aktivitas belajar siswa yang belum baik adalah hasil belajar siswa belum memuaskan, karena rata-rata nilai baru mencapai 65 dengan ketuntasan belajar klasikal hanya 36\% atau hanya 8 siswa yang mampu memperoleh nilai di atas 75. Demikian juga dengan perilaku siswa, sebagian siswa belum menunjukkan perilaku yang baik dalam hal misalnya (1) tanggung jawab menyelesaikan tugas; (2) bertanya atau menjawab dalam diskusi kelompok; dan (3) keaktifan dalam diskusi kelompok.

\section{Deskrispi Hasil Siklus I}

Siklus I terdiri dari 3 (tiga) kali pertemuan yaitu 2 (dua) kali pertemuan penyampaian materi dan 1 (satu) pertemuan untuk tes formatif. Pada Siklus I disajikan materi sifat-sifat segiempat dengan rincian pertemuan ke-1 (1 jam pelajaran): sifat-sifat persegipanjang, persegi, dan jajargenjang, pertemuan ke-2 (2 jam pelajaran): sifat-sifat belahketupat, layang-layang, dan trapesium, dilanjutkan permainan KSD kelompok, pertemuan ke-3 (2 jam pelajaran): permainan KSD individu, dilanjutkan 1 jam pelajaran untuk tes formatif Siklus I. pembelajaran menggunakan pembelajaran ELPSA dengan permainan KSD. Selama pembelajaran peneliti bekerja sama dengan kolaborator mengobservasi aktivitas belajar dan merekam pembelajaran. Setelah pembelajaran selesai pada pertemuan ke-4 dilakukan tes formatif Siklus I.

\section{Perencanaan Tindakan}

Kegiatan dalam perencanaan antara lain (1) menyusun RPP materi sifat-sifat segiempat. RPP mengimplementasikan model pembelajaran ELSPA dengan permainan KSD. Pengembangan penyusunan RPP sesuai karakteristik pelajaran Matematika dan sesuai kebutuhan siswa; (2) menyiapkan bahan ajar berupa Modul Matematika SMP kelas VII yang diterbitkan MGMP Matematika SMP Kabupaten Kendal; (3) menyiapkan Lembar Kerja Siswa Laboratorium Mini Matematika; (4) menyiapkan lembar kerja siswa untuk membuat ringkasan materi tentang sifat-sifat segiempat; (5) menyiapkan soal-soal untuk tes formatif Siklus I; (6) menyiapkan lembar pengamatan untuk mengamati situasi dan kondisi kegiatan pembelajaran; (7) menyiapkan pedoman wawancara; (8) menyiapkan angket respon siswa dan angket refleksi siswa dalam pembelajaran.

\section{Pelaksanaan Tindakan}

Berdasarkan RPP yang disusun maka dilakukan proses pembelajaran Matematika dengan menerapkan model pembelajaran ELPSA dengan permainan KSD. Kegiatan pembelajaran dilaksanakan oleh peneliti yang merupakan guru Matematika kelas VII A SMP N 2 Patean Kendal. Kegiatan pembelajaran diamati kolaborator guru Matematika kelas VIII yaitu Susiwi, S.Pd. Pelaksanaan pembelajaran dilakukan dalam 3 (tiga) kali pertemuan dengan rincian (1) pertemuaan ke-1 dengan materi sifat-sifat persegipanjang, persegi, dan jajargenjang; (2) pertemuan ke-2 dengan materi sifat-sifat belah ketupat, layang-layang, dan trapesium dilanjutkan dengan permainan KSD kelompok; (3) pertemuan ke-3 permainan KSD individu dilanjutkan dengan tes formatif Siklus I pada jam 10.50 s.d. 11.30. Pembelajaran dilakukan sesuai model pembelajaran ELPSA dengan permainan KSD dengan perincian sebagai berikut.

Pertemuan pertama mengenai materi sifat-sifat persegipanjang, persegi, dan jajargenjang. Proses pembelajaran dengan urutan sebagai berikut: (1) Kegiatan Pendahuluan, (a) Siswa dibimbing oleh guru untuk menciptakan suasana pembelajaran pembelajaran yang religius, empati, peduli, dan 
disiplin dengan cara guru mengucapkan salam, meminta siswa duduk dengan tertib, mengecek kehadiran siswa dengan fokus siswa yang tidak masuk dilanjutkan berdo'a sambil mendo'akan siswa yang sakit supaya segera sembuh; (b) Siswa diberi apersepsi dan motivasi oleh guru untuk menumbuhkan keingintahuan siswa dengan guru mengaitkan materi yang akan dipelajari siswa dengan pengetahuan awal siswa dengan cara mengajukan pertanyaan antara lain: Gambar apakah ini? (Guru menggambar persegi panjang, persegi, dan jajar genjang di papan tulis), Benda-benda apakah di sekitarmu yang berbentuk persegi panjang, persegi, dan jajar genjang? Motivasi: guru menyampaikan manfaat mempelajari dan menguasai materi persegi panjang, persegi, dan jajar genjang (Experiencies); (c) Guru menyampaikan tujuan dan model pembelajaran yang akan diterapkan guru serta mengharapkan siswa untuk selalu berpartisipasi aktif untuk melatih mandiri, percaya diri, bersikap demokratis dengan menghargai pendapat siswa lain; (2) Kegiatan Inti, (a) Untuk menumbuhkan sikap demokratis siswa diminta duduk berkelompok sesuai dengan kelompok yang telah dibentuk oleh guru (tiap kelompok terdiri dari 4 siswa). Selanjutnya guru mengeksplisitkan atau memunculkan pengalaman terdahulu yang dimiliki siswa dan menghubungkannya dengan pengetahuan dan pengalaman baru yang akan diperolehnya (dipelajari) dengan cara mengajukan pertanyaan-pertanyaan yang berkaitan dengan persegi panjang, persegi, dan jajar genjang. Misalnya "Buku yang saya pegang ini berbentuk apa? Benda yang saya pegang (guru memegang kertas berukuran $20 \mathrm{~cm} \times 20 \mathrm{~cm}$ ) berbentuk apa? Sebutkan benda-benda di sekitar kalian berbentuk persegi panjang, persegi, dan jajar genjang? (Experiencies, Application) (Eksplorasi); (b) Guru melakukan kegiatan pembelajaran yang secara aktif mengembangkan bahasa matematika tertentu agar dimaknai oleh pembelajar dengan cara guru menggunakan model persegi panjang, persegi, dan jajar genjang dari kertas, selanjutnya guru mengajukan pertanyaan-pertanyaan yang berkaitan dengan unsur persegi panjang, persegi, dan jajar genjang (Language, Pictures) (Eksplorasi); (c) Guru melakukan kegiatan pembelajaran yang memberikan pengalaman mengenal konsep matematika dalam bentuk gambar dengan cara guru mengambar persegi panjang, persegi, dan jajar genjang di papan tulis selanjutnya mengajukan pertanyaan kepada siswa gambar apa bangun apa? (Pictures, Symbols); (d) Guru melakukan kegiatan pembelajaran yang dapat mengubah atau melakukan transisi dari representasi gambar ke representasi simbol. Guru menggambar persegi panjang, persegi, dan jajar genjang. Siswa dilatih untuk berpikir logis, cerdas, tangguh, kerja keras, dan kritis dengan cara guru mengajukan pertanyaan-pertanyaan misalnya panjang persegi panjang disimbolkan $p$, lebar disimbolkan I, panjang sisi persegi disimbolkan s (Pictures, Symbols) (Elaborasi); (f) Guru melakukan kegiatan pembelajaran yang berusaha memahami signifikansi proses belajar dengan dengan mengaplikasikan pengetahuan baru dalam memecahkan masalah dalam konteks yang bermakna dengan cara guru membagikan kegiatan Laboratorium Mini Matematika I, II, III (Application) (Elaborasi); (g) Guru memfasilitasi kelompok yang masih mengalami kesulitan dalam menyelesaikan Laboratorium Mini Matematika I, II, III; (h) Guru memberikan kuis yang harus dijawab mandiri, anggota kelompok tidak boleh saling membantu; (i) Dengan bimbingan guru siswa membuat kesimpulan tentang persegi panjang, persegi. Jajar genjang (Konfirmasi); (3) Kegiatan Penutup (10 menit), (a) Dengan tanya jawab, siswa dibimbing untuk membuat rangkuman; (c) Refleksi proses pembelajaran; (d) Guru memberikan pekerjaan rumah/tugas mandiri.

Pertemuan kedua dengan materi sifat-sifat belahketupat, layang-layang, dan jajar genjang. Proses pembelajaran terlaksana dengan urutan sebagai berikut: (1) Kegiatan Pendahuluan, (a) Siswa dibimbing oleh guru untuk menciptakan suasana pembelajaran pembelajaran yang religius, empati, peduli, dan disiplin dengan cara guru mengucapkan salam, meminta siswa duduk dengan tertib, mengecek kehadiran siswa dengan fokus siswa yang tidak masuk dilanjutkan berdo'a sambil 
mendo'akan siswa yang sakit supaya segera sembuh; (b) Siswa diberi apersepsi dan motivasi oleh guru untuk menumbuhkan keingintahuan siswa dengan guru mengaitkan materi yang akan dipelajari siswa dengan pengetahuan awal siswa dengan cara mengajukan pertanyaan antara lain: Gambar apakah ini? (Guru menggambar belah ketupat, layang-layang, dan trapesium di papan tulis), Bendabenda apakah di sekitarmu yang berbentuk belah ketupat, layang-layang, dan trapesium? Motivasi: guru menyampaikan manfaat mempelajari dan menguasai materi belah ketupat, layang-layang, dan trapesium (Experiencies); (c) Guru menyampaikan tujuan dan model pembelajaran yang akan diterapkan guru serta mengharapkan siswa untuk selalu berpartisipasi aktif untuk melatih mandiri, percaya diri, bersikap demokratis dengan menghargai pendapat siswa lain; (2) Kegiatan Inti, (a) Untuk menumbuhkan sikap demokratis siswa diminta duduk berkelompok sesuai dengan kelompok yang telah dibentuk oleh guru (tiap kelompok terdiri dari 4 siswa). Selanjutnya guru mengeksplisitkan atau memunculkan pengalaman terdahulu yang dimiliki siswa dan menghubungkannya dengan pengetahuan dan pengalaman baru yang akan diperolehnya (dipelajari) dengan cara mengajukan pertanyaan-pertanyaan yang berkaitan dengan belah ketupat, layang-layang, dan trapesium. Misalnya "Buku yang saya pegang ini berbentuk apa? Benda yang saya pegang (guru memegang kertas berukuran $20 \mathrm{~cm} \times 20 \mathrm{~cm}$ ) berbentuk apa? Sebutkan benda-benda di sekitar kalian berbentuk belah ketupat, layang-layang, dan trapesium? (Experiencies, Application) (Eksplorasi); (b) Guru melakukan kegiatan pembelajaran yang secara aktif mengembangkan bahasa matematika tertentu agar dimaknai oleh pembelajar dengan cara guru menggunakan model belah ketupat, layang-layang, dan trapesium dari kertas, selanjutnya guru mengajukan pertanyaan-pertanyaan yang berkaitan dengan unsur belah ketupat, layang-layang, dan trapesium (Language, Pictures) (Eksplorasi); (c) Guru melakukan kegiatan pembelajaran yang memberikan pengalaman mengenal konsep matematika dalam bentuk gambar dengan cara guru mengambar belah ketupat, layang-layang, dan trapesium di papan tulis selanjutnya mengajukan pertanyaan kepada siswa gambar apa bangun apa? (Pictures, Symbols); (d) Guru melakukan kegiatan pembelajaran yang dapat mengubah atau melakukan transisi dari representasi gambar ke representasi simbol. Guru menggambar belah ketupat, layang-layang, dan trapesium. Siswa dilatih untuk berpikir logis, cerdas, tangguh, kerja keras, dan kritis dengan cara guru mengajukan pertanyaan-pertanyaan misalnya diagonal pertama disimbolkan $d_{1}$, diagonal kedua disimbolkan $d_{2}$, sisi-sisi sejajar pada trapesium disimbolkan a dan $b$ (Pictures, Symbols) (Elaborasi); (f) Guru melakukan kegiatan pembelajaran yang berusaha memahami signifikansi proses belajar dengan dengan mengaplikasikan pengetahuan baru dalam memecahkan masalah dalam konteks yang bermakna dengan cara guru membagikan kegiatan Laboratorium Mini Matematika IV, V, VI (Application) (Elaborasi); (g) Guru memfasilitasi kelompok yang mengalami kesulitan dalam menyelesaikan Laboratorium Mini Matematika IV, V, Vl; (h) Guru memberikan kuis yang harus dijawab mandiri, anggota kelompok tidak boleh saling membantu; (i) Dengan bimbingan guru siswa membuat kesimpulan tentang belah ketupat, layang-layang, dan trapesium (Konfirmasi); (j) Dilanjutkan permainan KSD kelompok; (3) Kegiatan Penutup (10 menit), (a) Dengan tanya jawab, siswa dibimbing untuk rangkuman; (c) Refleksi proses pembelajaran; (d) Guru memberikan pekerjaan rumah/tugas mandiri. Pertemuan ke- untuk permainan KSD individu dilanjutkan dengan tes formatif Siklus.

\section{Pengamatan}

Selama proses pembelajaran model ELSPA dengan permainan KSD, dilaksanakan pengamatan berpedoman lembar pengamatan atau penilaian proses oleh peneliti untuk mengetahui aktivitas belajar siswa. Rekapitulasi hasil pengamatan aktivitas siswa dalam pembelajaran dapat 
disimpulkan bahwa aktivitas belajar siswa pada proses pembelajaran dalam kategori baik dengan rata-rata $63 \%$. Aktivitas siswa dalam kategori baik antara lain (1) aktivitas visual/melihat (membaca buku paket atau modul atau bacaan lainnya yang relevan dengan materi segiempat); (2) Mendengarkan (mendengarkan penyajian bahan; mendengarkan percakapan atau diskusi); (3) Menulis (membuat rangkuman tentang segiempat pada LKSRM); (4) Menggambar (Menggambar/membuat sketsa dari segiempat); (5) Metrik (terlibat aktif dalam diskusi kelompok); dan (6) Emosional (minat dalam diskusi). Secara keseluruhan aktivitas siswa dalam proses pembelajaran pada kategori baik namun masih perlu untuk ditingkatkan karena rata-rata aktivitas baru mencapai $63 \%$. Walaupun rata-rata aktivitas dalam kategori baik, namun masih muncul aktivitas dalam kategori cukup baik yaitu (1) aktivitas oral/lisan (mengajukan pertanyaan pada pembelajaran, mengemukakan pendapat/berdiskusi dengan teman satu kelompok); dan (2) aktivitas mental (memecahkan masalah yang berkaitan dengan konsep segiempat).

Hasil wawancara dengan anak yang antusias dalam pembelajaran ELPSA dengan permainan KSD, pembelajaran menjadi menarik dan menyenangkan. Pelajaran yang sebelumnya dirasa sulit untuk dipahami, kini menjadi lebih mudah untuk dipahami dan diingat. Dengan permainan KSD materi sifat-sifat segiempat mudah mengingat sehingga mudah menerapkan sekaligus melakukan yang sebenarnya terjadi. Sedangkan siswa yang pasif hanya merasa sedikit tertarik dengan mata pelajaran Matematika apalagi mendengar kata "Matematika" masih merasa takut dan enggan untuk membaca dan mempelajari karena mereka merasa tidak bisa dan sulit mengingat dan menerapkannya. Lebih enak cerita dengan teman (ngrumpi) atau bergurau dengan teman bahkan ada yang menggunakan gunting dan penggaris untuk bemain sendiri ketika disuruh mengerjakan Laboratorium Mini Matematika.

Setelah siswa mengikuti proses pembelajaran ELPSA dengan permainan KSD, selanjutnya siswa mengerjakan tes formatif Siklus I diperoleh rata-rata aktivitas belajar siswa sebesar 63\% (kategori baik) namun rata-rata hasil belajar siswa baru mencapai sebesar 74 dengan ketuntasan belajar baru $59 \%$, sehingga belum mencapai indikator kinerja penelitian maka penelitian dilanjutkan pada Siklus II.

\section{Refleksi}

Berdasarkan hasil pengamatan dan wawancara dengan siswa, aktivitas siswa dalam pembelajaran mengalami peningkatan setelah diterapkan pembelajaran ELPSA dengan permainan KSD. Perbandingannya dapat dilihat pada Tabel 4.

Tabel 4. Perbandingan Hasil Belajar Siswa Kondisi Awal dan Siklus I.

\begin{tabular}{lrr}
\hline \multicolumn{1}{c}{ Uraian } & Kondisi Awal & \multicolumn{1}{c}{ Siklus I } \\
\hline KKM & 75 & 75 \\
\hline Nilai Tertinggi & 85 & 86 \\
\hline Nilai Terendah & 40 & 54 \\
\hline Rata-rata & 65 & 74 \\
\hline Jumlah SiswaTuntas & $8(36 \%)$ & $13(59 \%)$ \\
\hline Jumlah SiswaTidakTuntas & $14(64 \%)$ & $9(41 \%)$ \\
\hline
\end{tabular}

Berdasarkan Tabel 4, dapat disimpulkan bahwa pembelajaran ELPSA dengan permainan KSD dapat meningkatkan aktivitas siswa dalam pembelajaran dan hasil pembelajaran, namun belum 
memenuhi indikator penelitian sehingga penelitian dilanjutkan pada Siklus II.

\section{Deskrispi Hasil Siklus II}

Siklus II terdiri dari 4 pertemuan yaitu 3 pertemuan penyampaian materi dan 1 pertemuan untuk tes formatif. Pada Siklus II disajikan materi keliling dan luas segiempat dengan rincian pertemuan ke-1 (1 jam pelajaran): keliling dan luas persegipanjang dan persegi, pertemuan ke-2 (2 jam pelajaran): keliling dan luas jajargenjang, belahketupat, layang-layang, dan trapesium, pertemuan ke-3 (2 jam pelajaran): permainan KSD kelompok dan individu, dan pertemuan ke-4 untuk tes formatif Siklus II. Proses pembelajaran menggunakan pembelajaran ELPSA dengan permainan KSD. Selama proses pembelajaran peneliti bekerja sama dengan kolaborator mengobservasi aktivitas belajar dan merekam proses pembelajaran. Setelah proses pembelajaran selesai pada pertemuan ke-4 dilakukan tes formatif Siklus II.

\section{Perencanaan Tindakan}

Diawali dengan menyusun Rencana Pelaksanaan Pembelajaran (RPP) materi keliling dan luas segiempat yang mengimplementasikan model pembelajaran ELSPA dengan permainan KSD. Dalam perencanaan guru menyiapkan bahan ajar berupa Modul Matematika SMP kelas VII yang diterbitkan MGMP Matematika SMP Kabupaten Kendal, menyiapkan lembar kerja siswa untuk membuat ringkasan materi tentang keliling dan luas segiempat, menyiapkan Lembar Kerja Siswa Laboratorium Mini Matematika, menyiapkan soal untuk tes formatif Siklus II, menyiapkan lembar pengamatan untuk mengamati situasi dan kondisi kegiatan pembelajaran, menyiapkan pedoman wawancara, menyiapkan angket respon siswa dan angket refleksi siswa dalam pembelajaran.

\section{Pelaksanaan Tindakan}

Berdasarkan RPP yang disusun maka dilakukan proses pembelajaran Matematika dengan menerapkan model pembelajaran ELPSA dengan permainan KSD. Kegiatan pembelajaran dilaksanakan oleh peneliti yang merupakan guru Matematika kelas VII A SMP N 2 Patean Kendal. Kegiatan pembelajaran diamati kolaborator guru Matematika kelas VIII yaitu Susiwi, S.Pd. Pelaksanaan pembelajaran dilakukan dalam 3 (tiga) kali pertemuan dengan rincian (1) pertemuaan ke-1 dengan materi keliling dan luas persegipanjang dan persegi; (2) pertemuan ke-2 dengan materi keliling dan luas jajargenjang, belahketupat, layang-layang, dan trapesium; (3) pertemuan ke-3 permainan KSD Kelompok dilanjutkan permainan KSD Individu pada jam 10.50 s.d. 11.30; (4) tes formatif Siklus II. Pembelajaran dilakukan sesuai model pembelajaran ELPSA dengan permainan KSD dengan langkah-langkah sebagai berikut.

Pertemuan pertama dengan materi menentukan keliling dan luas persegi panjang dan persegi meliputi (1) Kegiatan Pendahuluan. (a) Siswa dibimbing oleh guru untuk menciptakan suasana pembelajaran yang religius, empati, peduli, dan disiplin dengan cara guru mengucapkan salam, meminta siswa duduk dengan tertib, mengecek kehadiran siswa dengan fokus siswa yang tidak masuk dilanjutkan berdo'a sambil mendo'akan siswa yang sakit supaya segera sembuh; (b) Siswa diberi apersepsi dan motivasi oleh guru untuk menumbuhkan keingintahuan siswa dengan guru mengaitkan materi yang akan dipelajari siswa dengan pengetahuan awal siswa dengan cara mengajukan pertanyaan antara lain: Gambar apakah ini? (Guru menggambar persegi panjang dan persegi di papan tulis), Benda-benda apakah di sekitarmu yang berbentuk persegi panjang dan persegi? Bagaimana cara menentukan keliling dan luas persegi panjang dan persegi? Motivasi: guru menyampaikan manfaat mempelajari dan menguasai materi persegi panjang dan persegi 
(Experiencies); (c) Guru menyampaikan tujuan dan model pembelajaran yang akan diterapkan guru serta mengharapkan siswa untuk selalu berpartisipasi aktif untuk melatih mandiri, percaya diri, bersikap demokratis dengan menghargai pendapat siswa lain. (2) Kegiatan Inti. (a) Untuk menumbuhkan sikap demokratis siswa diminta duduk berkelompok sesuai dengan kelompok yang telah dibentuk oleh guru (tiap kelompok terdiri dari 4 siswa). Selanjutnya guru mengeksplisitkan atau memunculkan pengalaman terdahulu yang dimiliki siswa dan menghubungkannya dengan pengetahuan dan pengalaman baru yang akan diperolehnya (dipelajari) dengan cara mengajukan pertanyaan-pertanyaan yang berkaitan dengan persegi panjang dan persegi. Misalnya "Buku yang saya pegang ini berbentuk apa? Benda yang saya pegang (guru memegang kertas berukuran $20 \mathrm{~cm}$ $\times 20 \mathrm{~cm}$ ) berbentuk apa? Sebutkan benda-benda di sekitar kalian berbentuk persegi panjang dan persegi? (Experiencies, Application) (Eksplorasi); (b) Guru melakukan kegiatan pembelajaran yang secara aktif mengembangkan bahasa matematika tertentu agar dimaknai oleh pembelajar dengan cara guru menggunakan model persegi panjang dan persegi dari kertas, selanjutnya guru mengajukan pertanyaan-pertanyaan yang berkaitan dengan keliling dan luas persegi panjang dan persegi (Language, Pictures) (Eksplorasi); (c) Guru melakukan kegiatan pembelajaran yang memberikan pengalaman mengenal konsep matematika dalam bentuk gambar dengan cara guru menggambar persegi panjang dan persegi di papan tulis selanjutnya mengajukan pertanyaan kepada siswa gambar apa bangun apa? (Pictures, Symbols); (d) Guru melakukan kegiatan pembelajaran yang dapat mengubah atau melakukan transisi dari representasi gambar ke representasi simbol. Guru menggambar persegi panjang dan persegi. Siswa dilatih untuk berpikir logis, cerdas, tangguh, kerja keras, dan kritis dengan cara guru mengajukan pertanyaan-pertanyaan misalnya panjang persegi panjang disimbolkan $p$, lebar disimbolkan I, panjang sisi persegi disimbolkan $s, \mathrm{~K}=$ keliling dan L = Luas (Pictures, Symbols) (Elaborasi); (e) Guru melakukan kegiatan pembelajaran yang berusaha memahami signifikansi proses belajar dengan dengan mengaplikasikan pengetahuan baru dalam memecahkan masalah dalam konteks yang bermakna dengan cara guru membagikan kegiatan LMM VII, VIII (Laboratorium Mini Matematika) VII, VIII (Application) (Elaborasi); (f) Guru memfasilitasi kelompok yang masih mengalami kesulitan dalam menyelesaikan kegiatan LMM VII, VIII (Laboratorium Mini Matematika VII, VIII); (h) Guru memberikan kuis yang harus dijawab mandiri, anggota kelompok tidak boleh saling membantu; (i) Dengan bimbingan guru siswa membuat kesimpulan tentang menentukan keliling dan luas persegi panjang dan persegi (Konfirmasi). (3) Kegiatan Penutup. (a) Dengan tanya jawab, siswa dibimbing untuk membuat rangkuman materi menentukan luas dan keliling persegi panjang dan persegi; (b) Refleksi proses pembelajaran; (c) Guru memberikan pekerjaan rumah/tugas mandiri.

Pertemuan kedua dengan materi keliling dan luas jajargenjang, belahketupat, layang-layang, dan trapesium. Sama seperti kegiatan pada pertemuan pertama dilanjutkan pada Kegiatan Inti. Untuk menumbuhkan sikap demokratis siswa diminta duduk berkelompok sesuai dengan kelompok yang telah dibentuk oleh guru (tiap kelompok terdiri dari 4 siswa). Guru melakukan pembelajaran secara aktif mengembangkan bahasa matematika tertentu agar dimaknai oleh pembelajar dengan cara guru menggunakan model jajargenjang, belahketupat, layang-layang, dan trapesium dari kertas, selanjutnya guru mengajukan pertanyaan yang berkaitan dengan keliling dan luas jajargenjang, belahketupat, layang-layang, dan trapesium (Language, Pictures) (Eksplorasi Guru melakukan kegiatan pembelajaran yang dapat mengubah atau melakukan transisi dari representasi gambar ke representasi simbol. Guru menggambar jajargenjang, belahketupat, layang-layang, dan trapesium. Siswa dilatih untuk berpikir logis, cerdas, tangguh, kerja keras, dan kritis dengan cara guru mengajukan pertanyaan-pertanyaan misalnya pada belah ketupat dan layang-layang diagonal 
pertama disimbolkan $d_{1}$, diagonal kedua disimbolkan $d_{2}$, dua sisi trapesium yang sejajar disimbolkan $a$ dan $b, \mathrm{~K}=$ keliling dan $\mathrm{L}=$ Luas (Pictures, Symbols) (Elaborasi); Guru melakukan kegiatan pembelajaran yang berusaha memahami signifikansi proses belajar dengan dengan mengaplikasikan pengetahuan baru dalam memecahkan masalah dalam konteks yang bermakna dengan cara guru membagikan kegiatan Laboratorium Mini Matematika IX, X, XI, dan XII (Application) (Elaborasi); dan memfasilitasi kelompok yang masih mengalami kesulitan dalam menyelesaikan kegiatan Laboratorium Mini Matematika. Guru memberikan kuis yang harus dijawab mandiri, anggota kelompok tidak boleh saling membantu.(i) Dengan bimbingan guru siswa membuat kesimpulan (Konfirmasi). (3) Kegiatan Penutup. (a) Dengan tanya jawab, siswa dibimbing untuk membuat rangkuman; (b) Refleksi proses pembelajaran; (c) Guru memberikan pekerjaan rumah/tugas mandiri.

Pertemuan ketiga, Selama pembelajaran model ELSPA dengan permainan KSD, berpedoman lembar pengamatan atau penilaian proses oleh peneliti untuk mengetahui aktivitas belajar siswa bahwa aktivitas belajar siswa pada proses pembelajaran dalam kategori baik dengan rata-rata $76 \%$. Aktivitas siswa dalam kategori baik antara lain (1) aktivitas visual/melihat (membaca buku paket/modul/bacaan lainnya yang relevan dengan materi segiempat); (2) aktivitas oral/lisan (mengajukan pertanyaan pada pembelajaran, mengemukakan pendapat/berdiskusi dengan teman satu kelompok), (3) Mendengarkan (penyajian bahan; percakapan atau diskusi); (4) Menggambar sketsa dari segiempat); (5) Metrik, terlibat aktif dalam diskusi kelompok); (6) Mental, memecahkan masalah yang berkaitan dengan konsep segiempat, dan (7) Emosional minat dalam diskusi. Bahkan untuk Aktivitas Menulis (membuat rangkuman tentang segiempat pada Lembar Kegiatan Siswa Rangkuman Materi (LKSRM) pada kategori baik. dengan rata-rata aktivitas mencapai 76\%.

Hasil wawancara dengan anak yang antusias dalam pembelajaran ELPSA dengan permainan KSD, pembelajaran menjadi menarik dan menyenangkan. Pelajaran yang sebelumnya dirasa sulit untuk dipahami, kini menjadi lebih mudah untuk dipahami dan diingat. Dengan permainan KSD materi keliling dan luas segiempat mudah mengingat sehingga mudah menerapkan sekaligus melakukan yang sebenarnya terjadi. Sedangkan siswa yang pasif hanya merasa sedikit tertarik dengan mata pelajaran Matematika apalagi mendengar kata "Matematika" masih merasa takut dan enggan untuk membaca dan mempelajari karena mereka merasa tidak bisa dan sulit mengingat dan menerapkannya. Lebih enak cerita dengan teman (ngrumpi) atau bergurau dengan teman bahkan ada yang menggunakan gunting dan penggaris untuk bemain sendiri ketika disuruh mengerjakan Laboratorium Mini Matematika. Setelah siswa mengikuti proses pembelajaran ELPSA dengan permainan KSD, selanjutnya siswa mengerjakan tes formatif Siklus II. Rata-rata aktivitas belajar siswa sebesar 75\% (kategori baik), rata-rata hasil belajar siswa sebesar 85 , dengan ketuntasan belajar mencapai $86 \%$ sudah mencapai indikator kinerja penelitian sehingga penelitian cukup sampai pada Siklus II saja.

\section{Refleksi}

Berdasarkan hasil pengamatan dan wawancara dengan siswa, aktivitas siswa dalam pembelajaran mengalami peningkatan setelah diterapkan pembelajaran ELPSA dengan permainan KSD. Peningkatan aktivitas siswa dapat dilihat pada Tabel 5. 
Tabel 5. Perbandingan Aktivitas Siswa dalam Pembelajaran Siklus I dan Siklus II.

\begin{tabular}{|c|c|c|c|c|}
\hline \multirow{2}{*}{ Jenis Aktivitas } & \multicolumn{2}{|c|}{ Siklus I } & \multicolumn{2}{|c|}{ Siklus II } \\
\hline & Rata-2 & Kriteria & Rata-2 & Kriteria \\
\hline Visual/melihat & $65 \%$ & B & $79 \%$ & B \\
\hline Oral/Lisan & $58 \%$ & CB & $69 \%$ & $B$ \\
\hline Mendengarkan & $65 \%$ & $B$ & $78 \%$ & $B$ \\
\hline Menggambar & $72 \%$ & $B$ & $84 \%$ & SB \\
\hline Menulis & $65 \%$ & $B$ & $81 \%$ & $B$ \\
\hline Metrik & $65 \%$ & $B$ & $75 \%$ & $B$ \\
\hline Mental & $50 \%$ & CB & $64 \%$ & $B$ \\
\hline Emosional & $67 \%$ & $B$ & $78 \%$ & B \\
\hline Rata-rata & $63 \%$ & $B$ & $76 \%$ & B \\
\hline
\end{tabular}

Penerapan model pembelajaran ELPSA dengan permainan KSD juga meningkatkan hasil belajar siswa seperti peningkatan nilai tertinggi, nilai terendah, dan ketuntasan belajar siswa selengkapnya dapat dilihat pada Tabel 6.

Tabel 6. Perbandingan Hasil Belajar Siswa Siklus I dan Siklus II.

\begin{tabular}{|c|c|c|}
\hline Uraian & Siklus I & Siklus II \\
\hline KKM & 75 & 75 \\
\hline NilaiTertinggi & 86 & 100 \\
\hline NilaiTerendah & 54 & 58 \\
\hline Rata-rata & 74 & 85 \\
\hline Jumlah SiswaTuntas & $13(51 \%)$ & $19(86 \%)$ \\
\hline Jumlah SiswaTidakTuntas & $9(41 \%)$ & $3(14 \%)$ \\
\hline
\end{tabular}

Sehingga, dapat disimpulkan bahwa pembelajaran ELPSA dengan permainan KSD dapat meningkatkan aktivitas siswa dalam pembelajaran dan hasil pembelajaran, sudah memenuhi indikator penelitian sehingga penelitian cukup sampai pada Siklus II.

\section{Pembahasan Hasil Penelitian}

Pembahasan dibedakan menjadi 2 (dua) yaitu pembahasan hasil belajar dan aktivitas siswa.

\section{Hasil Belajar}

Hasil belajar siswa berdasarkan nilai tes formatif mengalami peningkatan setelah dilakukan pembelajaran ELPSA dengan permainan KSD dalam 2 (dua) siklus. Pada Siklus I guru menerapkan pembelajaran ELPSA dengan permainan KSD materi Sifat-sifat segiempat, Siklus II materi keliling dan luas segiempat. Maka dapat disimpulkan bahwa pembelajaran ELPSA dengan permainan KSD telah meningkatkan hasil belajar siswa dilihat dari nilai tertinggi, nilai terendah, rata-rata, dan ketuntasan belajar. Pada Siklus I nilai tertinggi 86 meningkat 14 point menjadi 100 pada Siklus II, nilai terendah 54 meningkat 4 point menjadi 58 pada Siklus II, rata-rata nilai 74 meningkat 12 point menjadi 86 , dan ketuntasan belajar $51 \%$ meningkat $35 \%$ menjadi $86 \%$.

Dengan demikian komponen hasil belajar ditinjau dari aspek nilai tertinggi, nilai terendah, rata-rata nilai, dan ketuntasan belajar telah memenuhi indikator kinerja penelitian, sehingga hipotesis penelitian yang menyatakan hasil belajar siswa kelas VII A SMPN 2 Patean Kendal Semester 2 
Tahun Pelajaran 2015/2016 dapat ditingkatkan melalui pembelajaran ELPSA dengan permainan KSD dapat ditingkatkan diterima. Hasil penelitian ini memperkuat pendapat Prof. Tom Lowrie dari Charles Sturt University Australia, ketua tim RIPPLE (Research Institute for Professional Practice, Learning \& Education) bahwa model ELPSA dikembangkan berdasarkan pada teori pembelajaran konstruktivisme dan sifatnya sosial. Pada Model ELPSA, pembelajaran sebagai suatu proses aktif dan siswa mengkonstruksi sendiri dalam memahami sesuatu melalui proses berpikir individu dan interaksi sosial dengan orang lain (Adi Wijaya dkk. 2014) yang memperkuat hasil penelitian Mustakim dan Solikhin (2015) bahwa permaian KSD dalam pembelajaran Matematika bahwa permainan KSD dapat meningkat hasil belajar siswa.

\section{Aktivitas Siswa}

Aktivitas siswa dalam pembelajaran mengalami peningkatan setelah dilakukan pembelajaran ELPSA dengan permainan KSD dalam 2 (dua) siklus. Pada Siklus I guru menerapkan pembelajaran ELPSA dengan permainan KSD materi sifat-sifat segiempat. Pada Siklus II guru menerapkan pembelajaran ELPSA dengan permainan KSD dengan penyempurnaan tindakan untuk materi keliling dan luas segiempat. Peningkatan aktivitas siswa dalam belajar dan penyempurnaan tindakan dari kondisi awal, Siklus I, dan Siklus II dapat disimak semua aspek aktivitas siswa dalam belajar mengalamai peningkatan baik aktivitas visual, oral, mendengarkan, menulis, mengambar, metrik, mental, maupun emosional. Pada Siklus I penerapan model pembelajaran ELPSA dengan permainan KSD mampu meningkatkan aktivitas siswa dalam belajar sebesar $21 \%$ dari $42 \%$ menjadi $63 \%$. Pada Siklus I aktivitas siswa dalam belajar belum tercapai. Karena indikator kinerja penelitian belum tercapai, maka penelitian dilanjutkan pada Siklus II meliputi beberapa faktor yaitu (1) penelitian direncanakan dua siklus, (2) mengetahui peningkatan aktivitas siswa dalam pembelajaran sesaat atau berkelanjutan, dan (3) membuktikan keefektifan model pembelajaran ELPSA dengan permainan KSD. Pada Siklus II penerapan model pembelajaran ELPSA dengan permainan KSD mampu meningkatkan aktivitas siswa dalam belajar sebesar $13 \%$ dari $63 \%$ menjadi $76 \%$.

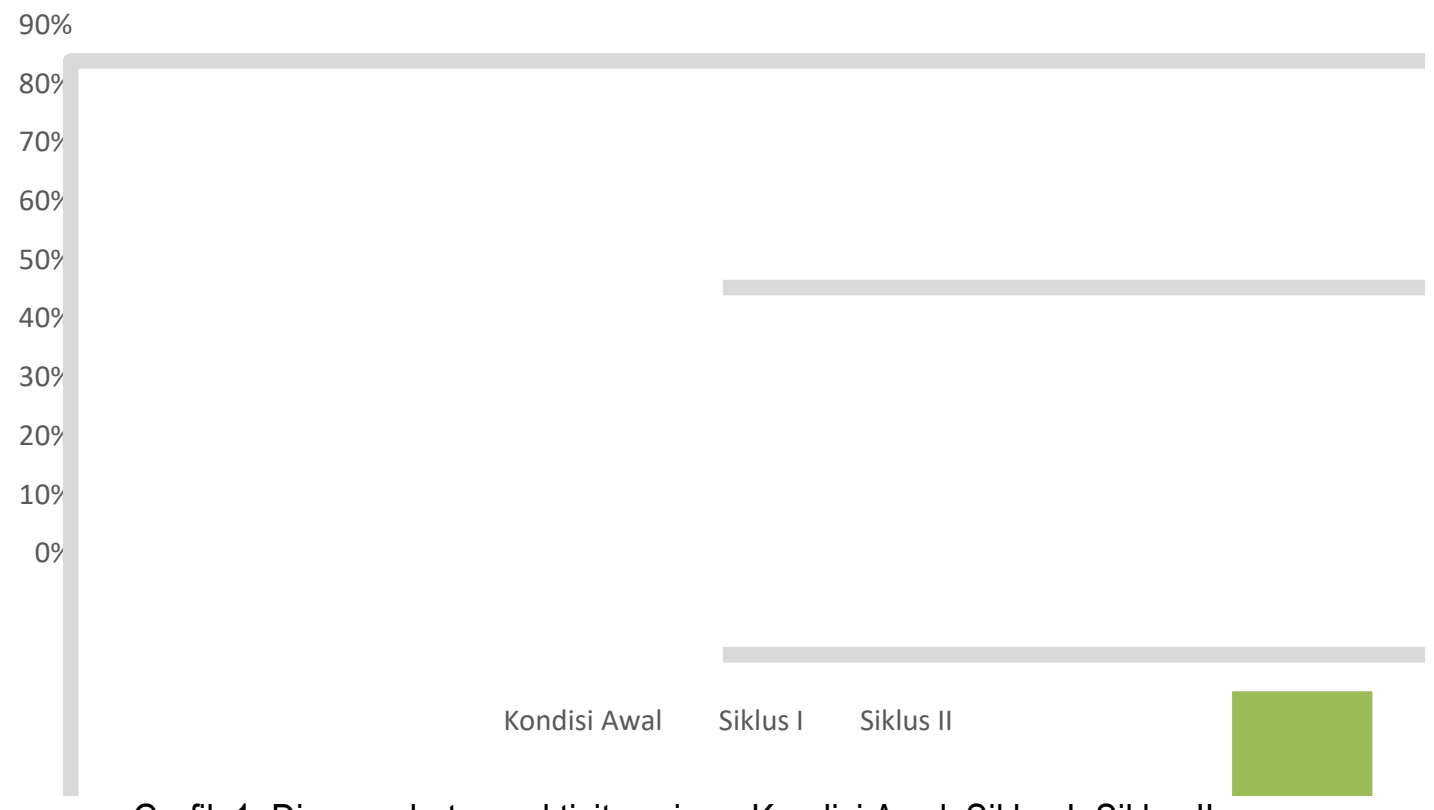

Grafik 1. Diagram batang aktivitas siswa Kondisi Awal, Siklus I, Siklus II 
Dengan demikian pada Siklus II kenierja penelitian untuk aktivitas siswa dalam belajar telah tercapai. Berdasarkan data Siklus II, pembelajaran ELPSA dengan permainan KSD terbukti mampu meningkatkan aktivitas siswa dalam belajar. Indikator kinerja penelitian $75 \%$ aktivitas siswa dalam pembelajaran berkategori baik tercapai, dan aktivitas siswa dapat ditingkatkan melalui pembelajaran ELPSA dengan permainan KSD dapat diterima. Menurut Slameto (2010) yang menyatakan bahwa faktor eksternal dengan sistem lingkungan belajar mempengaruhi aktivitas siswa. Penerapan pembelajaran ELPSA dengan permainan KSD dilakukan guru merupakan salah satu faktor eksternal yang mempengaruhi aktivitas siswa. Peningkatan aktivitas siswa dalam belajar dipaparkan pada Grafik 1.

\section{SIMPULAN}

Dari hasil PTK ini diperoleh simpulan bahwa: Proses pembelajaran ELPSA dengan permainan KSD dapat meningkatkan hasil belajar Matematika materi segiempat siswa kelas VII-A SMPN 2 Patean Kendal Semester 2 Tahun Pelajaran 2015/2016 dan dapat mengubah perilaku siswa kelas VII A SMPN 2 Patean Kendal Semester 2 Tahun Pelajaran 2015/2016.

\section{REFERENSI}

Adi Wijaya. (2014). Modul ELPSA: Kerangka Pembelajaran ELPSA Modul Suplemen Diklat Online Kerjasama PPPPTK Matematika-The World Bank 2014. Yogyakarta: PPPPTK MATEMATIKA.

Adi Wijaya. (2014). Pengenalan Desain Pembelajaran ELPSA (EXPERIENCES, LANGUAGE, PICTURES, SYMBOLS, APPLICATION). Yogyakarta: PPPPTK MATEMATIKA.

Dewi Nuharini \& Tri Wahyuni. (2008). Matematika Konsep dan Aplikasinya untuk kelas VII SMP dan MTs. Jakarta: Departemen Pendidikan Nasional Pusat Perbukuan.

Fajar, Arnie. (2005). Portofolio dalam Pelajaran IPS. Bandung: PT Remaja Rosdakarya.

Hamalik, Oemar. (2011). Proses Belajar Mengajar. Jakarta: Bumi Aksara.

http://118.98.234.50/hun/daya_serap.aspx diakses hari Rabu tanggal 7 Januari 2016 jam 21.00 WIB M.S. Wahyudi, Dyah Rini P, Mustakim, \& Muh. Arief K. (2014). Materi Pengayaan Matematika untuk SMP/MTs. Kelas 7. Kendal: MGMP Matematika Kabupaten Kendal.

Mustakim \& Solikhin. (2015). Upaya Meningkatkan Keberanian Siswa Bertanya dan Prestasi Belajar dengan Pembelajaran Think Pair Share (TPS) Berbantuan Media Permainan Kuis Siapa Dia pada Materi Segitiga dan Segiempat Bagi Siswa Kelas VII A SMP Negeri 2 Patean Semester 2 Tahun Pelajaran 2014/2015. Jurnal Pendidikan UT. Volume 16 No 2 September Tahun 2015. ISSN (Print): 1411-1942 ISSN (Online): 2443-3586.

Mustakim. (2015). Merancang Rencana Pelaksanaan Pembelajaran (RPP) dengan Model Pembelajaran ELPSA Materi Bangun Datar Segiempat. Jurnal Integral, vol 2. No 1 April 2015. ISSN: ISSN : 2355-4681.

Suprijono, Agus. (2010). Cooperatif Learning Teori dan Aplikasi PAIKEM. Yogyakarta: Pustaka Pelajar.

Slameto. (2010). Belajar dan Faktor-faktor yang Mempengaruhi. Jakarta: Rineka Cipta. 